\title{
Effects of 17 -estradiol, Interleukin-1 $\beta$, and Human Chorionic Gonadotropin on Activity and mRNA Expression of Plasminogen Activators in Porcine Endometrial Cells
}

\author{
Yong Hwangbo ${ }^{1}$, Hee-Tae Cheong ${ }^{2}$, Boo-Keun Yang ${ }^{1}$, and ${ }^{\dagger}$ Choon-Keun Park ${ }^{1}$ \\ ${ }^{1}$ College of Animal Life Sciences, Kangwon National University, Chuncheon 24341, Korea \\ ${ }^{2}$ College of Veterinary Medicine, Kangwon National University, Chunchoen 24341, Korea
}

\begin{abstract}
This study aimed to investigate changes in the activity and mRNA expression of plasminogen activators (PAs) induced by $17 \beta$-estradiol $\left(\mathrm{E}_{2}\right)$, human chorionic gonadotropin (hCG), and interleukin-1 $\beta$ (IL-1 $\beta$ ) in porcine endometrial cells. Endometrial cells were isolated from the epithelium and cultured to $80 \%$ confluence. They were then treated for $24 \mathrm{~h}$ with $\mathrm{E}_{2}$ $(0.2,2,20$, and $200 \mathrm{ng} / \mathrm{mL})$, IL- $1 \beta(0.1,1,10$, and $100 \mathrm{ng} / \mathrm{mL})$, and hCG $(0.5,1,1.5$ and $2 \mathrm{IU} / \mathrm{mL})$. mRNA expressions of urokinase-type (uPA) and tissue-type (tPA) PAs were analyzed using reverse transcription PCR, and activities were measured using a PA activity assay. mRNA expressions of uPA and tPA increased with $\mathrm{E}_{2}$ treatment; however, this was not significant. Similarly, treatment with hCG did not influence the mRNA expressions of PAs. Interestingly, treatment with $0.1 \mathrm{ng} / \mathrm{mL} \mathrm{IL}-1 \beta$ significantly reduced the mRNA expression of uPA, but did not affect that of tPA. Treatment with 2, 20, and $200 \mathrm{ng} / \mathrm{mL} \mathrm{E}_{2}$ increased PA activity compared with the control group; treatment with 0.1 and $1 \mathrm{ng} / \mathrm{mL}$ IL- $1 \beta$ significantly increased PA activity compared with the other IL- $1 \beta$ treatment groups, whereas treatment with 10 and $100 \mathrm{ng} / \mathrm{mL}$ IL- $1 \beta$ decreased. Treatment with $2 \mathrm{IU} / \mathrm{mL}$ hCG increased PA activity compared with the other treatment groups, although there were no significant differences between the hCG and control groups. In conclusion, the activity and mRNA expression of PAs were differently regulated by the hormone/cytokine and its concentration in porcine endometrial cells. Therefore, understanding PA regulatory mechanisms may help to improve the reproductive potential of domestic animals.
\end{abstract}

Key words : 17 -estradiol, Human chorionic gonadotropin, Interleukin-1 $\beta$, Plasminogen activators, Porcine endometrial cells

\section{INTRODUCTION}

The uterus secretes various growth factors, cytokines, and nutrients essential for embryo growth, implantation, and gestation. During the estrous cycle, it undergoes morphological and physiological changes such as increased thickness of the glandular epithelium and endometrium, angiogenesis, gene expression, and cytokine secretion (Stroband et al., 1986; Baker et al., 1998; Demir et al., 2010;
Franczak et al., 2013). In particular, tissue remodeling of the mammalian uterus, which includes angiogenesis and increased number of secretory cells in the endometrium, provides a suitable environment for the survival and growth of the embryo and implantation of the conceptus. These changes within the uterine microenvironment are regulated by gonadotropins, hormones, and cytokines.

Estrogen is one of the main sex hormones of the female reproductive system and plays an important role in repro-

\footnotetext{
Manuscript received June 6, 2018, Received in revised form June 20, 2018, Accepted June 26, 2018

${ }^{\dagger}$ Corresponding Author : Choon-Keun Park, College of Animal Life Sciences, Kangwon National University, Chuncheon 24341, Korea. Tel.: +82-33250-8627, E-mail: parkck@kangwon.ac.kr
}

This is an Open Access article distributed under the terms of the Creative Commons Attribution Non-Commercial License (http:// creative-commons.org/licenses/by-nc/3.0) which permits unrestricted non-commercial use, distribution, and reproduction in any medium, provided the original work is properly cited. 
ductive processes, such as uterine tissue remodeling and implantation recognition (Bazer \& Johnson, 2014). This hormone is secreted from the ovaries and affects the endometrium blood vessels. In particular, the porcine conceptus produces $17 \beta$-estradiol $\left(E_{2}\right)$, a type of estrogen that prepares the endometrium for implantation during the preimplantation period (Bazer \& Johnson, 2014).

Human chorionic gonadotropin (hCG) has the same receptor and similar function as luteinizing hormone (LH) (Bolzan et al., 2013). Generally, it has been used for the induction of estrous and ovulation in pigs (Wongkaweewit et al., 2013) and cows (Giordano et al., 2012). In the mammalian endometrium, prostaglandin (PG) synthesis is regulated by LH via increased PG-endoperoxide synthase 2 in uterine cells, and the uterine environment is altered to begin the luteal phase (Sugino, 2014).

Interleukin-1 $\beta$ (IL-1 $\beta$ ) from the conceptus is an important cytokine for implantation in pigs and plays a role in implantation and gestation as an autocrine and/or paracrine factor (Bazer \& Johnson, 2014). As a paracrine factor, IL-1 $\beta$ acts on luminal epithelial cells through its receptors (interleukin-1 receptor, IL-1R) (Subramaniam et al., 2004). Thus, understanding the effects of hormones and cytokines on endometrial cells is highly important.

Plasminogen activators (PAs) are serine proteases that are present in two forms-urokinase-type (uPA) and tissue-type (tPA) - in most extracellular fluids, including seminal plasma (Kobayashi et al., 1992), uterine and oviductal fluid (Finlay et al., 1983; Kouba et al., 2000), and ovarian fluid (Beers, 1975). The plasmin converted from plasminogen by the PAs directly or indirectly degrades the extracellular matrix (ECM). Because of this feature, the PA system is associated with physiological processes including angiogenesis (Olofsson et al., 1998), activation of growth factors in the ECM (Menshikov et al., 2006), cell migration (Ploplis et al., 1998), and tissue remodeling (Martin and Arias, 1982). In addition, the PA system regulates the reproductive process. The two types of PAs are released from mammalian cumulus-oocyte complexes and are related to oocyte maturation and fertilization (Ebisch et al., 2008); moreover, plasma and acrosomal membranes of spermatozoa contain PAs to help penetrate the zona pellucida (Sa et al., 2010). In addition, epithelial cells in the oviducts and uterus express PAs and their inhibitors during the estrous cycle (Ahn et al., 2009; Hwangbo et al., 2013). Despite the PA system being closely associated with reproductive processes in the mammalian uterus, mechanisms underlying the regulation and activation of PAs in the uterus of domestic animals remain unclear. Therefore, the present study aimed to investigate changes in the activity and mRNA expression of PAs induced by $E_{2}$, hCG, and IL-1 $\beta$ in porcine endometrial cells.

\section{MATERIALS AND METHODS}

\section{Preparation of endometrial cells and treatment}

A porcine uterus was collected from a local slaughterhouse and transported to the laboratory within $2 \mathrm{~h}$ on ice. The uterus was washed using Hank's Balanced Salt Solution (HBSS) and the ovaries and mesometrium were removed. The inside of the uterus was flushed using HBSS. The uterine horns were then cut along the vertical axis and epithelial cells were collected in Dulbecco's Modified Eagle's Medium (DMEM, Invitrogen, MA, USA) containing collagenase type I ( $66 \mathrm{unit} / \mathrm{mL}$ ) by gently scraping the endometrial epithelium using a surgical blade. Epithelial cells were incubated in a shaking incubator $\left(38^{\circ} \mathrm{C}, 120\right.$ rpm) to isolate them from the tissues. Isolated cells were filtered using a cell strainer (SPL Life Sciences, Korea) and centrifuged at 1,200 g for $5 \mathrm{~min}$. Blood components were removed using Tris- $\mathrm{NH}_{4}$ and washed in HBSS. Collected cells were cultured in DMEM/F-12 containing 10\% (v/v) FBS (Invitrogen), 0.2\% (v/v) amphotericin B (Sigma-Aldrich, St. Louis, MO, USA), and $0.5 \%(\mathrm{v} / \mathrm{v})$ antibiotic-antimycotic (ABAM, Invitrogen) at $38.5^{\circ} \mathrm{C}$ in a $5 \%$ $\mathrm{CO}_{2}$ incubator, and the culture medium was changed every 
48 h. When cells reached $80 \%$ confluence, different concentrations of $\mathrm{E}_{2}(0.2,2,20$, and $200 \mathrm{ng} / \mathrm{mL}), \mathrm{IL}-1 \beta(0.1$, 1, 10, and $100 \mathrm{ng} / \mathrm{mL})$, or hCG $(0.5,1,1.5$ and $2 \mathrm{IU} / \mathrm{mL})$ were added for $24 \mathrm{~h}$.

\section{Reverse transcription PCR}

For mRNA extraction from cells, samples were treated with RNAiso Plus (Takara, Japan) and rotated for $10 \mathrm{~min}$. Chloroform was then added to the RNAiso Plus followed by vortexing for $5 \mathrm{~min}$. Extracted mRNA was separated by centrifugation $\left(12,000 \mathrm{~g}, 4^{\circ} \mathrm{C}, 5 \mathrm{~min}\right)$ and washed with isopropyl alcohol followed by $75 \%$ ethanol. The dried mRNA pellet was mixed with DEPC-treated de-ionized water and mRNA concentrations were determined using the NanoDrop 2000 (Thermo Scientfic Nanodrop, Wilmington, DE, USA). cDNA was synthesized using Maxime RT PreMix (Intron Biotechnology, Korea) and PCR was conducted using primers (Table 1). The identities of PCR products were confirmed by $2 \%$ agarose gel electrophoresis containing ethidium bromide (EtBr, Bioneer, Korea). The relative mRNA expressions of uPA and $\mathrm{PPA}$ were normalized to GAPDH (glyceraldehyde 3-phosphate dehydrogenase), and ImageJ was used for image analysis.

\section{PA activity assay}

Samples of the collected culture medium $(20 \mu \mathrm{L})$ were dispensed into a 96-well microplate and mixed with $30 \mu \mathrm{L}$ of a plasminogen working solution (Sigma-Aldrich). The solution was incubated at $38^{\circ} \mathrm{C}$ for $1 \mathrm{~h}$. After incubation, substrate buffer [0.18 mM Z-L-Lys-SBzl hydrochloride, $0.22 \mathrm{mM} 5,5^{\prime}$-dithiobis-(2-nitrobenzoic acid), and $0.01 \%$ Triton X-100] was added and was further incubated at $38^{\circ} \mathrm{C}$ for $1 \mathrm{~h}$. PA activity was determined by absorbance at the wavelength of $405 \mathrm{~nm}$ using a microplate reader.

\section{Statistical analysis}

All numerical data representing each parameter were analyzed using Statistical Analysis System software (SAS, version 9.4). Data are represented as the means \pm standard error of the mean (SEM) and were analyzed using Duncan's multiple range test. Comparisons among treatment groups were conducted using a generalized linear model in the SAS package. A value of $p<0.05$ was considered statistically significant.

\section{RESULTS}

1. Effects of $E_{2}, I L-1 \beta$, and hCG on mRNA expression of UPA and TPA in endometrial epithelial cells

Although the mRNA expression of uPA and tPA increased in $E_{2}$-treated uterine cells, this was not significant (Fig. 1). Interestingly, treatment with $0.1 \mathrm{ng} / \mathrm{mL}$ IL-1 $\beta$ significantly reduced the mRNA expression of uPA (Fig. $2 \mathrm{~A}, p<0.05)$, whereas that of tPA remained unchanged.

Table 1. Primer sequences for reverse transcription PCR

\begin{tabular}{clcc}
\hline \hline Gene & \multicolumn{1}{c}{ Primer sequence } & Product size (bp) & Accession \\
\hline \multirow{2}{*}{ uPA } & $\begin{array}{l}\text { F:CCTACAAGTACTTCTC } \\
\text { R:GCAAACCAAGGCTGGTTTCTC }\end{array}$ & 460 & NM_213945 \\
\hline \multirow{2}{*}{ tPA } & $\begin{array}{l}\text { F:AGGAGGCCTCTATGCTGACA } \\
\text { R:GGCACACAGCATATTGTTGG }\end{array}$ & 544 & NM_214054 \\
\hline \multirow{2}{*}{ GAPDH } & $\begin{array}{l}\text { F:AAATGGGCACGTTGTGGGTG } \\
\text { R:AGGCCAACCGGGAGAAGATG }\end{array}$ & 200 & AF017079 \\
\hline
\end{tabular}

uPA, urokinase-type plasminogen activator; tPA, tissue-type plasminogen activator; GAPDH, glyceraldehyde 3-phosphate dehydrogenase. 
(A)

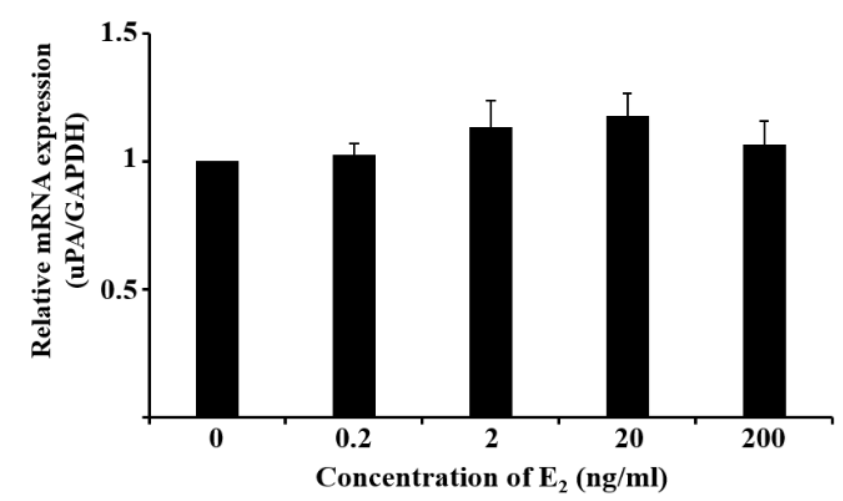

(B)

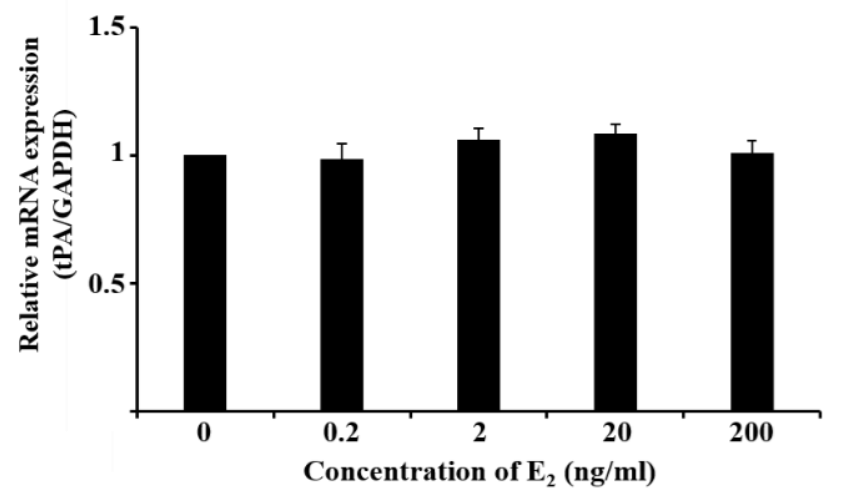

Fig. 1. Effect of 17ß-estradiol $\left(E_{2} ; 0,0.2,2,20\right.$, and $\left.200 \mathrm{ng} / \mathrm{mL}\right)$ on the mRNA expression of two types of plasminogen activator (urokinase-type: uPA, A; tissue-type: tPA, B) in porcine endometrial cells. All data were presented as mean \pm SEM from 3 repeated experiments. PA, plasminogen activator; GAPDH, glyceraldehyde 3-phosphate dehydrogenase.

Similar to the latter finding, the mRNA expression of neither PA was altered by hCG (Fig. 3).

2. Change in PA activity induced by $E_{2}, I L-1 \beta$, and hCG treatment in endometrial epithelial cells

PA activity significantly increased following treatment with 2, 20, and $200 \mathrm{ng} / \mathrm{mL} \mathrm{E}_{2}$ compared with the control group (Fig. 4A, $p<0.05$ ), which was similar to the tendency in the mRNA expression of PAs to increase. Treatment with 0.1 and $1 \mathrm{ng} / \mathrm{mL}$ IL-1 $\beta$ significantly increased PA activity compared with the other groups, whereas 10 and 100 ng/mL IL-1 $\beta$ decreased PA activity (Fig. 4B, $p<0.05$ ). This pattern of PA activity was contrary to the mRNA expression of $u P A$ seen following IL-1 $\beta$ treatment. Unlike mRNA expression, PA activity increased in $2 \mathrm{IU} / \mathrm{mL}$ hCGtreated cells compared with the other treatment groups; however, none of the hCG groups were significantly different from the control group (Fig. 4C).
(A)

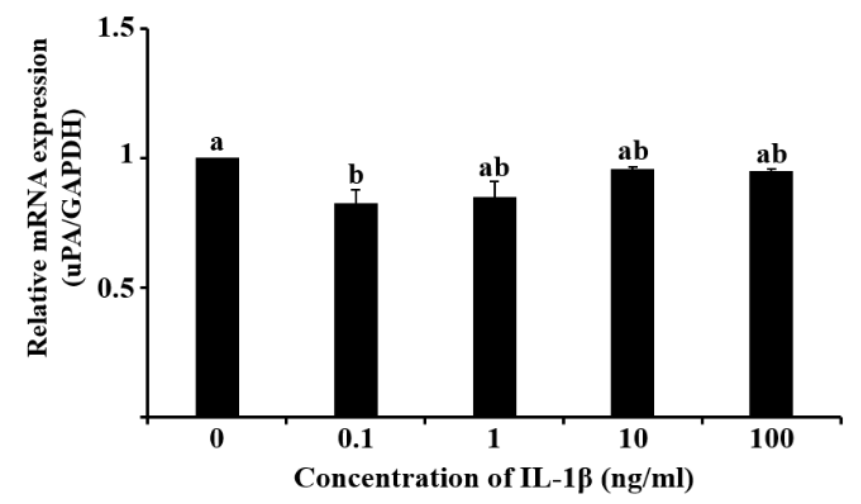

(B)

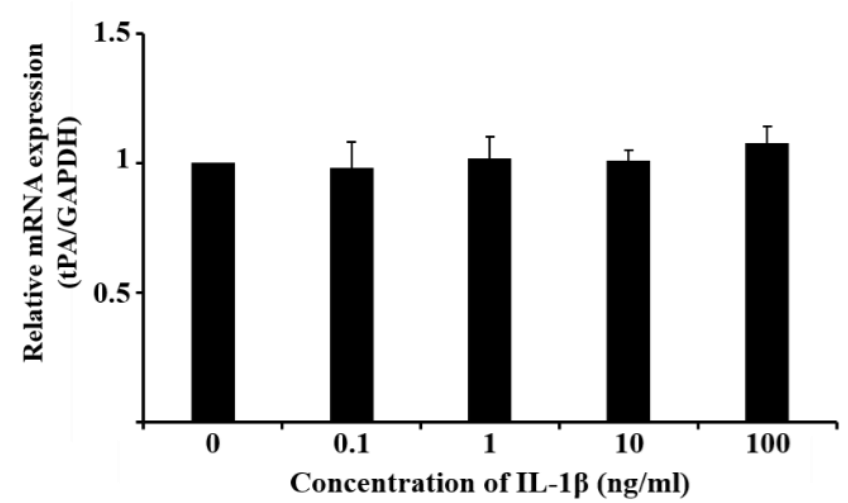

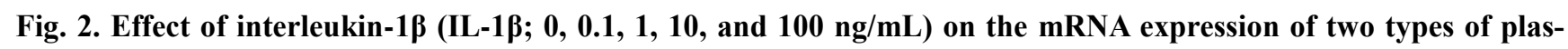
minogen activator (urokinase-type: uPA, A; tissue-type: tPA, B) in porcine endometrial cells. All data were presented as mean \pm SEM from 3 repeated experiments. ${ }^{\mathrm{a}, \mathrm{b}}$ Different superscript indicates a significant difference $(p<0.05)$. PA, plasminogen activator; GAPDH, glyceraldehyde 3-phosphate dehydrogenase. 
(A)

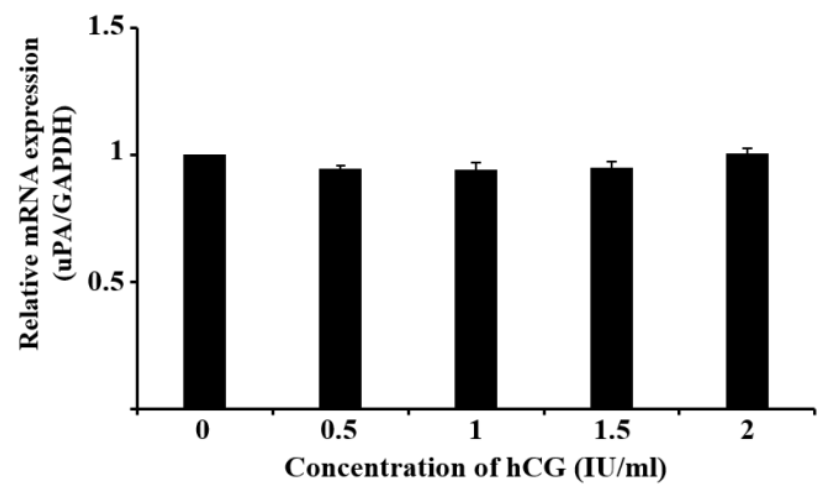

(B)

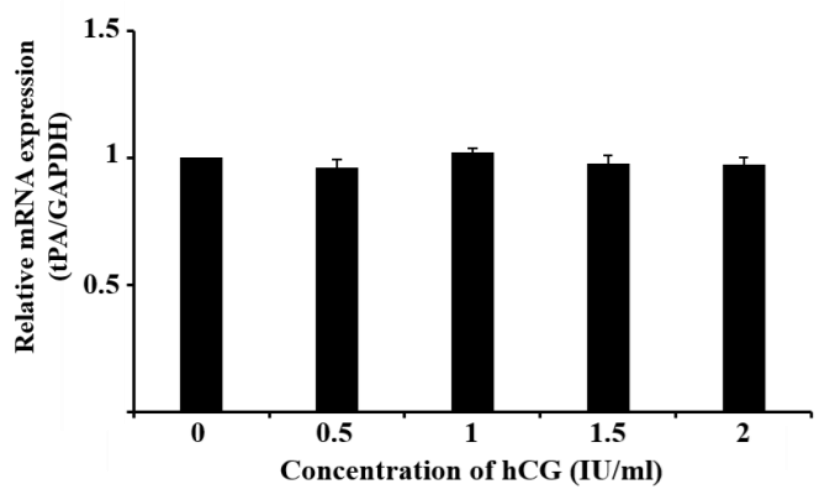

Fig. 3. Effect of human chorionic gonadotropin (hCG; $0,0.5,1,1.5$, and $2 \mathrm{IU} / \mathrm{mL}$ ) on the $\mathrm{mRNA}$ expression of two types of plasminogen activator (urokinase-type: uPA, A; tissue-type: tPA, B) in porcine endometrial cells. All data were presented as mean \pm SEM from 3 repeated experiments. PA, plasminogen activator; hCG, human chorionic gonadotropin; GAPDH, glyceraldehyde 3-phosphate dehydrogenase.

(A)

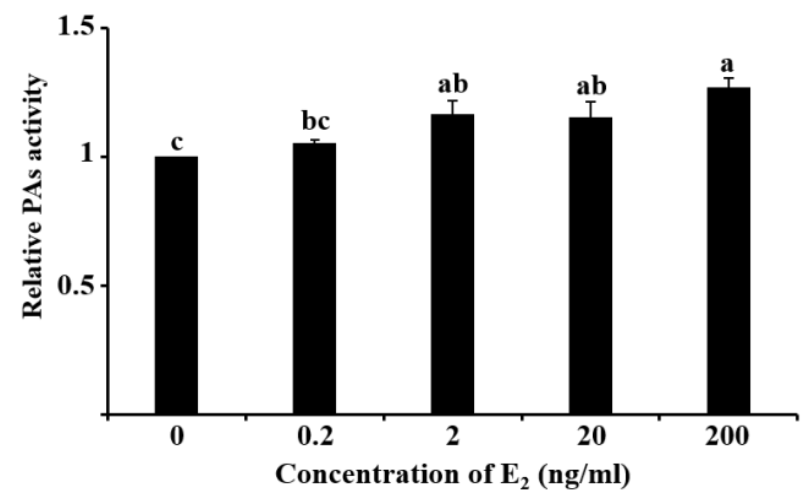

(C)

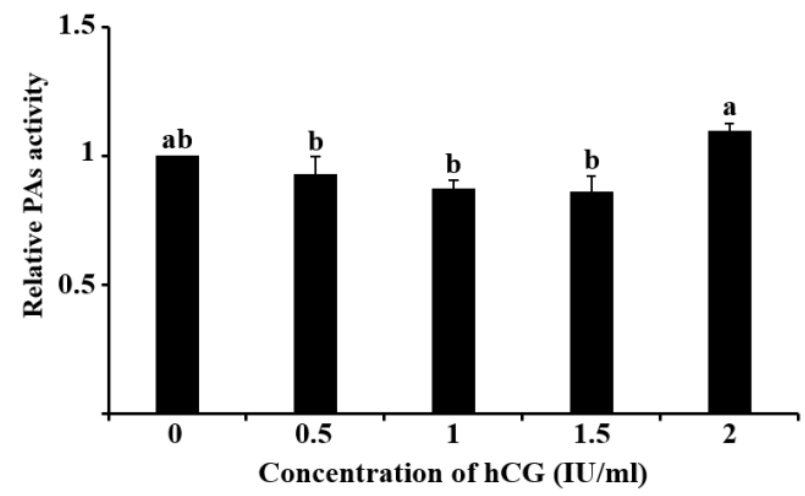

(B)

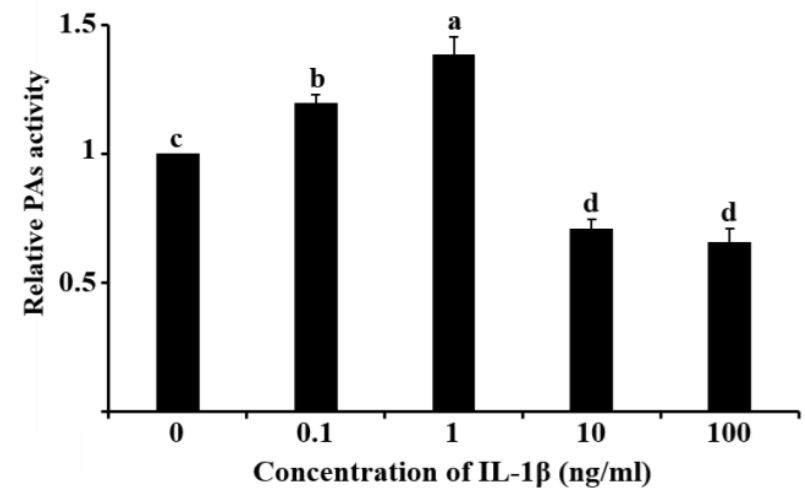

Fig. 4. Changes in plasminogen activator activity induced by different concentrations of $17 \beta$-estradiol $\left(E_{2} ; 0,0.2,2\right.$,

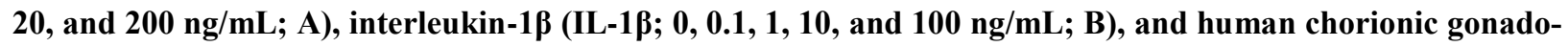
tropin (hCG; $0,0.5,1,1.5$, and $2 \mathrm{IU} / \mathrm{mL} ; \mathrm{C}$ ) in porcine endometrial cells. All data were presented as mean \pm SEM from 3 repeated experiments. ${ }^{a-c}$ Different superscript indicates a significant difference $(p<0.05)$. PA, plasminogen activator; hCG, human chorionic gonadotropin; GAPDH, glyceraldehyde 3-phosphate dehydrogenase. 


\section{DISCUSSION}

This study was conducted to confirm the effects of $E_{2}$, hCG, or IL-1 $\beta$ on the mRNA expression and activity of two types of PA in porcine endometrial epithelial cells. mRNA expression of uPA decreased only with $0.1 \mathrm{ng} / \mathrm{mL}$ IL-1 $\beta$ treatment, whereas that of tPA remained unchanged. Interestingly, altered PA activity resulting from treatment with different concentrations of $\mathrm{E}_{2}$ showed a similar pattern to mRNA expression of PA. Conversely, a pattern of PA activity that was different from that of the mRNA expression of uPA was seen after IL-1 $\beta$ treatment.

During the estrous cycle in mammals, morphological and physiological features of the uterus are altered by a number of hormones, cytokines, and chemokines, and these are important for the survival of the embryo, implantation, and successful pregnancy. Cheon (2007) reported that collagens in the early-pregnant mouse uterus are regulated for successful implantation and pregnancy. In addition, the expression of various genes and proteins that act as essential regulators of uterine function and its microenvironment is controlled through the actions of hormones and cytokines during the estrous cycle. As tissue remodeling factors, PAs are present in the uterine tissue and their levels are altered during the estrous cycle (Kim et al., 2011). They play a role in reproductive and physiological processes including angiogenesis, oocyte maturation, embryo development, ovulation, activation of matrix metalloproteinases (MMPs), and degradation of collagens and ECM proteins (Ebisch et al., 2008). In particular, spermzona pellucida binding is decreased by both PAs in the cytoplasm and zona pellucida of porcine oocytes during fertilization (Coy et al., 2012), and Krania et al. (2015) reported that addition of tPA during the in vitro fertilization of bovine oocytes decreased embryo development and increased the expression of apoptosis-related genes in embryos. Therefore, regulatory mechanisms underlying PA mRNA expression and activation in the female reproduc- tive tract are important for animal reproduction.

Steroid hormones, including estrogen, progesterone, and androgens, play a pivotal role in uterine endometrial function in mammals (Cheon et al., 2009). During endometrial growth in the rat uterus, the thickness of the luminal epithelium increased with estrogen treatment (Lai et al., 2000). Estrogen and progesterone regulate reproduction via genomic and non-genomic actions (Stormshak \& Bishop, 2008). In the present study, treatment with $E_{2}$ enhanced PA activity, but did not influence the mRNA expression of PA. This suggests that estrogen may has influenced to translation or post-translation processes for the activation of PAs via non-genomic actions. Furthermore, we expect that an $\mathrm{E}_{2}$-induced increase in PA activity could be responsible for the tissue remodeling associated with angiogenesis, increased growth of the glandular epithelium, and enhanced thickness of the endometrium during the estrous cycle and implantation in pigs. However, effects of estrogen on the translational and post-translational processes of PAs in porcine endometrial cells require further research.

Generally, hCG has been used to induce ovulation in pigs (Brussow et al., 2009). As hCG has a similar structure to $\mathrm{LH}$, it interacts with the $\mathrm{LH}$ receptor within the ovary. During the estrous cycle in pigs, a rapid increase in $\mathrm{LH}$ concentration known as the LH surge occurs before ovulation, inducing ovulation through rupture of the ovarian wall. At the same time, both uPA and IPA are produced in the granulosa and thecal cells of rat follicles by gonadotropins (Ny et al., 1985; Liu et al., 1987). Kim et al. (2011) reported that PA activity in porcine uterine tissue increased during the post-ovulatory period compared with the preovulatory period. In this study, the activation of PAs in endometrial cells was stimulated by $2 \mathrm{IU} / \mathrm{mL}$ hCG treatment. In the uterus and oviducts, hCG influences PG synthase expression and PG synthesis (Shemesh et al., 2001; Malysz-Cymborska et al., 2013), and the actions of hCG in the female reproductive tract are important for gamete transport and survival. PA activity stimulated by hCG may 
play a role in uterine tissue remodeling and regulation of the intrauterine environment, thereby enabling embryo survival.

During the pre-implantation period, the conceptus trophectoderm of the pig secretes IL-1 $\beta$, which is associated with elongation and pregnancy recognition (Ross et al., 2003). Interaction between the endometrium and conceptus via IL-1 $\beta$ is an important phenomenon for successful implantation in pigs. In addition, proliferation of uterine epithelial cells is stimulated by IL- $1 \beta$ via activation of the extracellular signal-regulated kinase (ERK) 1/2 mitogenactivated protein kinase (MAPK) signaling cascade (Jeong et al., 2016). In the present study, the mRNA expression of uPA was reduced by a low concentration of IL-1 $1 \beta$, although tPA mRNA was not affected. PA activity increased in the low concentration groups $(0.1$ and $1 \mathrm{ng} / \mathrm{mL})$, whereas it decreased by 10 and $100 \mathrm{ng} / \mathrm{mL}$ IL-1 $\beta$. ERK/MAPK signaling regulates cellular processes including gene expression, protein synthesis, cell migration, and proliferation. The activation of IL-1 $\beta$-induced ERK/MAPK signaling has been reported to be dose- and time-dependent (Jeong et al., 2016). Ny et al (1985) reported that the two types of PAs were differently regulated in granulosa cells by gonadotropins. Therefore, differential patterns of the mRNA expression of PA and PA activity may be regulated by the IL-1 $\beta$-mediated ERK/MAPK signaling cascade.

In this work, we found that the mRNA expression of uPA and tPA is differently regulated by IL- $1 \beta$ in porcine endometrial cells, and treatment with $\mathrm{E}_{2}$, hCG, or IL-1 $\beta$ influenced the activation of PAs. During the estrous cycle and implantation period, the PA system plays an important role in tissue remodeling, including angiogenesis and effects on secretory glands and thickness of the endometrium. These results suggest that regulation of PA expression and activation by hormones and cytokines in the porcine uterus is critical for successful pregnancy. Understanding the PA regulatory mechanism may help improve the reproductive potential of domestic animals.

\section{ACKNOWLEDGEMENTS}

This work was supported by the National Research Foundation of Korea (NRF) grant funded by the Korea government (Ministry of Education) (2016R1D1A1B03931746) and this study was supported by 2017 Research Grant from Kanwon national University (No. 520170230).

\section{REFERENCES}

Ahn SH, Cheong HT, Yang BK, Kim DY, Park CK (2009) Relationship between plasminogen activity and plasminogen inhibitor during the culture of porcine oviduct epithelial cells. Reprod Dev Biol 33:203-209.

Baker VL, Draper M, Paul S, Allerheiligen S, Glant M, Shifren J, Jaffe RB (1998) Reproductive endocrine and endometrial effects of raloxifene hydrochloride, a selective estrogen receptor modulator, in women with regular menstrual cycles 1. J Clin Endocrinol Metab 83:6-13.

Bazer FW, Johnson GA (2014) Pig blastocyst-uterine interactions. Differentiation 87:52-65.

Beers WH (1975) Follicular plasminogen and plasminogen activator and the effect of plasmin on ovarian follicle wall. Cell 6:379-386.

Bolzan E, Andronowska A, Bodek G, Morawska-Pucinska E, Krawczynski K, Dabrowski A, Ziecik AJ (2013) The novel effect of hCG administration on luteal function maintenance during the estrous cycle/pregnancy and early embryo development in the pig. Pol J Vet Sci 16: 323-332.

Brussow KP, Schneider F, Kanitz W, Ratky J, Kauffold J, Wahner M (2009) Studies on fixed-time ovulation induction in the pig. Soc Reprod Fertil Suppl 66:187195.

Cheon YP (2007) Altering of collagens in early pregnant mouse uterus. Dev Reprod 11:1-11.

Cheon YP, Lee DM, Chun TH, Lee KH, Choi IH (2009) 
Androgen in the uterus: A compensator of estrogen and progesterone. Dev Reprod 13:133-143.

Coy P, Jimenez-Movilla M, Garcia-Vazquez FA, Mondejar I, Grullon L, Romar R (2012) Oocytes use the plasminogen-plasmin system to remove supernumerary spermatozoa. Hum Reprod 27:1985-1993.

Demir R, Yaba A, Huppertz B (2010) Vasculogenesis and angiogenesis in the endometrium during menstrual cycle and implantation. Acta Histochem 112:203-214.

Ebisch IMW, Thomas CMG, Wetzels AMM, Willemsen WNP, Sweep FCGJ, Steegers-Theunissen RPM (2008) Review of the role of the plasminogen activators system and vascular endothelial growth factor in subfertility. Fertil Steril 90:2340-2350.

Finlay TH, Katz J, Kirsch L, Levitz M, Nathoo SA, Seiler S (1983) Estrogen-stimulated uptake of plasminogen by the mouse uterus. Endocrinology 112:856-861.

Franczak A, Wojciechowicz B, Kotwica G (2013) Transcriptomic analysis of the porcine endometrium during early pregnancy and the estrous cycle. Reprod Biol 13:229-237.

Giordano JO, Wiltbank MC, Guenther JN, Ares MS, Lopes Jr G, Herlihy MM, Fricke PM (2012) Effect of presynchronization with human chorionic gonadotropin or gonadotropin-releasing hormone 7 days before resynchronization of ovulation on fertility in lactating dairy cows. J Dairy Sci 95:5612-5625.

Hwangbo Y, Lee SH, Cha HJ, Song EJ, Lee ST, Lee ES, Cheong HT, Yang BK, Park CK (2013) Expression of plasminogen activators in uterine epithelial cells of pre-ovulatory phase in pigs. J Emb Trans 28:257-263.

Jeong W, Kim J, Bazer FW, Song G, Kim J (2016) Stimulatory effects of interleukin-1 beta on development of porcine uterine epithelial cell are mediated by activation of the ERK1/2 MAPK cell signaling cascade. Mol Cell Endocrinol 419:225-234.

Kim KH, Lee YS, Gu HN, Yang BK, Cheong HT, Park CK (2011) Changes in plasminogen activity in uterus tissue during the estrous cycle in the pigs. Reprod Dev Biol 35:463-468.

Kobayashi T, Matsuda Y, Park JY, Hara I, Kaneko S, Fujimoto Y, Nozawa S, Akihama S (1992) Trypsin-like arginine amidases including plasminogen and plasmin in human seminal plasma by affinity adsorption and elution. Arch Androl 28:165-170.

Kouba AJ, Burkhardt BR, Alvarez IM, Goodenow MM, Buhi WC (2000) Oviductal plasminogen activator inhibitor (PAI-1): mRNA, protein, and hormonal regulation during the estrous cycle and early pregnancy in the pig. Mol Reprod Dev 56:378-386.

Krania F, Dovolou E, Rekkas CA, Theodosiadou EK, Pappas I, Amiridis GS (2015) Effects of addition of tissuetype plasminogen activator in in vitro fertilization medium on bovine embryo development and quality. Reprod Domest Anim 50:112-120.

Lai MD, Lee LR, Cheng KS, Wing LY (2000) Expression of proliferating cell nuclear antigen in luminal epithelium during the growth and regression of rat uterus. J Endocrinol 166:87-93.

Liu YX, Cajander SB, Ny T, Kristensen P, Hsueh AJW (1987) Gonadotropin regulation of tissue-type and urokinase-type plasminogen activators in rat granulosa and theca-interstitial cells during the periovulatory period. Mol Cell Endocrinol 54:221-229.

Malysz-Cymborska I, Ziecik AJ, Waclawik A, Andronowska A (2013) Effect of hCG and eCG treatments on prostaglandins synthesis in the porcine oviduct. Reprod Domest Anim 48:1034-1042.

Martin O, Arias F (1982) Plasminogen activator production by trophoblast cells in vitro: Effect of steroid hormones and protein synthesis inhibitors. Am J Obstet Gynecol 142:402-409.

Menshikov M, Plekhanova O, Cai H, Chalupsky K, Parfyonova Y, Bashtrikov P, Tkachuk V, Berk BC (2006) Urokinase plasminogen activator stimulates vascular smooth muscle cell proliferation via redox-dependent 
pathways. Arterioscler Thromb Vasc Biol 26:801-807.

Ny T, Bjersing L, Hsueh AJW, Loskutoff DJ (1985) Cultured granulosa cells produce two plasminogen activators and an ant iactivator, each regulated differently by gonadotropins. Endocrinology 166:1666-1668.

Olofsson B, Korpelainen E, Pepper MS, Mandriota SJ, Aase K, Kumar V, Gunji Y, Jeltsch MM, Shibuya M, Alitalo K, Eriksson U (1998) Vascular endothelial growth factor B (VEGF-B) binds to VEGF receptor-1 and regulates plasminogen activator activity in endothelial cells. Proc Natl Acad Sci USA 95:11709-11714.

Ploplis VA, French EL, Carmeliet P, Collen D, Plow EF (1998) Plasminogen deficiency differentially affects recruitment of inflammatory cell populations in mice. Blood 91:2005-2009.

Ross JW, Ashworth MD, Hurst AG, Malayer JR, Geisert RD (2003) Analysis and characterization of differential gene expression during rapid trophoblastic elongation in the pig using suppression subtractive hybridization. Reprod Biol Endocrinol 1:23.

Sa SJ, Park CK, Kim IC, Lee SH, Kwon OS, Kim MJ, Cho KH, Kim DW, So KM, Cheong HT (2010) Effects of reactive oxygen species (ROS) on sperm function and plasminogen activator activity in porcine spermatozoa. Reprod Dev Biol 34:185-191.

Shemesh M, Mizrachi D, Gurevich M, Shore LS, Reed J,
Chang SM, Thatcher WW, Fields MJ (2001) Expression of functional luteinizing hormone $(\mathrm{LH})$ receptor and its messenger ribonucleic acid in bovine endometrium: LH augmentation of cAMP and inositol phosphate in vitro and human chorionic gonadotropin (hCG) augmentation of peripheral prostaglandin in vivo. Reprod Biol 1:13-32.

Stormshak F, Bishop CV (2008) Board-invited review: Estrogen and progesterone signaling: Genomic and nongenomic actions in domestic ruminants. J Anim Sci 86:299-315.

Stroband HWJ, Taverne N, Langenfeld K, Barends PMG (1986) The ultrastructure of the uterine epithelium of the pig during the estrous cycle and early pregnancy. Cell Tissue Res 246:81-89.

Subramaniam S, Stansberg C, Cunningham C (2004) The interleukin 1 receptor family. Dev Comp Immunol 28: 415-428.

Sugino N (2014) Molecular mechanisms of luteinization. Obstet Gynecol Sci 57:93-101.

Wongkaweewit K, Prommachart P, Raksasub R, Buranaamnuay K, Techakumphu M, De Rensis F, Tummaruk $\mathrm{P}$ (2012) Effect of the administration of GnRH or hCG on time of ovulation and the onset of estrus-toovulation interval in sows in Thailand. Trop Anim Health Pro 44:467-470. 